\title{
Diet of the southern opah Lampris immaculatus on the Patagonian Shelf; the significance of the squid Moroteuthis ingens and anthropogenic plastic
}

\author{
George D. Jackson ${ }^{1, *}$, Nicole G. Buxton ${ }^{2}$, Magnus J. A. George ${ }^{3}$ \\ ${ }^{1}$ Institute of Antarctic and Southern Ocean Studies, University of Tasmania, GPO Box 252-77, Hobart, Tasmania 7001, Australia \\ ${ }^{2}$ Synergy Information Systems Ltd, PO Box 236, Stanley, Falkland Islands \\ ${ }^{3}$ Falkland Islands Government Fisheries Department, PO Box 122, Stanley, Falkland Islands
}

\begin{abstract}
The diet of the large pelagic fish, the southern opah Lampris immaculatus was examined along the Patagonian Shelf in the Falkland Islands region. Stomachs were available for 69 fish collected in 1993 and 1994. Surprisingly, this fish had a relatively narrow range of prey items. The single most frequent prey item was the onychoteuthid squid Moroteuthis ingens (predominantly juveniles) which was eaten by $93 \%$ of the fish. The other important prey were the loliginid squid Loligo gahi, the myctophid fish Gymnoscopelus nicholsi and the southern blue whiting Micromesistius australis. There was no evidence of larger individuals of $L$. immaculatus ingesting larger individuals of any of the 4 main prey species. An unexpected finding was the relatively high incidence of plastic ingestion (14\% of fish). The plastic came from a variety of sources including food, napkin and cigarette wrappers and various pieces of plastic line and straps used in securing boxes. In several instances, there was evidence of feeding on fishing boat discards. The findings reveal a significant impact of plastic pollution in this region of the Southwest Atlantic.
\end{abstract}

KEY WORDS: Stomach content analysis $\cdot$ Plastic pollution $\cdot$ Cephalopods $\cdot$ Otoliths

\section{INTRODUCTION}

Little is known of the biology and ecological role of the southern opah Lampris immaculatus (Gilchrist 1947), a large pelagic teleost which has a circumglobal distribution in the Southern Hemisphere (Parin \& Kukuyev 1983, Gon 1990). Gon (1990) described its diet consisting of krill, squid and fish and Prut'ko (1979) found 18 fish (Paradiplospinus antarcticus) and 1 unidentified squid in 1 individual from the Indian Ocean. In the past L. immaculatus has been considered a rare fish (Heemstra 1986). However, in recent years, scientific observers working for the Falkland Islands Government Fisheries Department have recorded that $L$. immaculatus is being taken as a bycatch in a number of fisheries operating in the waters of the Falkland Islands Interim Conservation

*E-mail: george.jackson@utas.edu.au and Management Zone (FICZ) and the Falklands Outer Conservation Zone (FOCZ). Pelagic trawlers which target the southern blue whiting Micromesistius australis capture L. immaculatus in particular. The maximum number of L. immaculatus recorded from 1987 to 1994 in a single trawl was 10.

Routine biological sampling of commercial trawls around the Falkland Islands showed that Lampris immaculatus preyed on large numbers of the onychoteuthid squid Moroteuthis ingens. This species is widely distributed within the FICZ and FOCZ (Jackson et al. 1998a), reaches lengths of over $500 \mathrm{~mm}$ mantle length (ML), weights in excess of $5 \mathrm{~kg}$ (Jackson \& Mladenov 1994) and appears to live for $1 \mathrm{yr}$ (Arkhipkin \& Bizikov 1991, Jackson 1997). M. ingens is an important prey item for a variety of mammals, birds and fish (Imber 1991, Cherel et al. 1993, Green \& Burton 1993, Cherel et al. 1996, Weimerskirch et al. 1997, Jackson et al. 1998a). 
Cephalopods have been identified as important food items in the diet of some elasmobranch and teleost predators, including oceanic sharks (Dunning et al. 1993); the deep water shark Lago omanensis (Waller \& Baranes 1994); squaloid sharks (Ebert et al. 1992); the Cape hakes Merluccinus capensis and M. paradoxus (Lipinski et al.1992); swordfish Xiphias gladius (Toll \& Hess 1981, Bello 1991, Guerra et al. 1993, Seki 1993); the demersal fish assemblage of Sendai Bay, Japan (Yamamura et al.1993); and the pomfret Brama japonica (Kubodera \& Shimazaki 1989). Most of these predators feed opportunistically on a number of different cephalopod species. Numerous studies have shown cephalopods to be of lesser importance to other fish species. For example, cephalopods constituted up to $11.6 \%$ (by mass) of the diet of Carcharhinus amblyrhynchos specimens which were taken from offshore samples in the Gulf of Carpentaria, Australia, but which were absent in estuary specimens (Salini et al. 1992).

This study was undertaken concurrently with a study of the biology of Moroteuthis ingens in the Falkland Islands region (e.g. Jackson et al. 1997, 1998a). Since it was observed that Lampris immaculatus appeared to eat large numbers of $M$. ingens, this study was aimed at describing and quantifying the diet of $L$. immaculatus around the Falkland Islands, and at describing the predator-prey relationship between this fish and M. ingens.

\section{METHODS}

Between September 1993 and November 1994, scientific observers employed by the Falkland Islands Government Fisheries Department (FIFD) stationed aboard trawlers within the Falkland Islands region of the Patagonian Shelf sampled all Lampris immaculatus individuals during their routine biological work (Fig. 1). Each fish was measured to the nearest $\mathrm{cm}$ below total length and weighed to the nearest kg. Stomachs were dissected out from above the cardiac sphincter to below the pyloric sphincter, and frozen for subsequent analysis on shore. Prior to analysis, the stomachs were fully defrosted, and weighed to the nearest gram. The stomach contents were removed and the internal folds were sluiced down with fresh water to dislodge any items trapped within the folds. The empty stomach was then weighed to determine the total weight of the contents by subtraction.

The stomach contents were divided into species, and each class was then subdivided by digestion stage and weighed to the nearest gram after Jackson et al. (1998b). All food items were identified to the lowest possible taxon and anthropogenic waste was identified and measured.

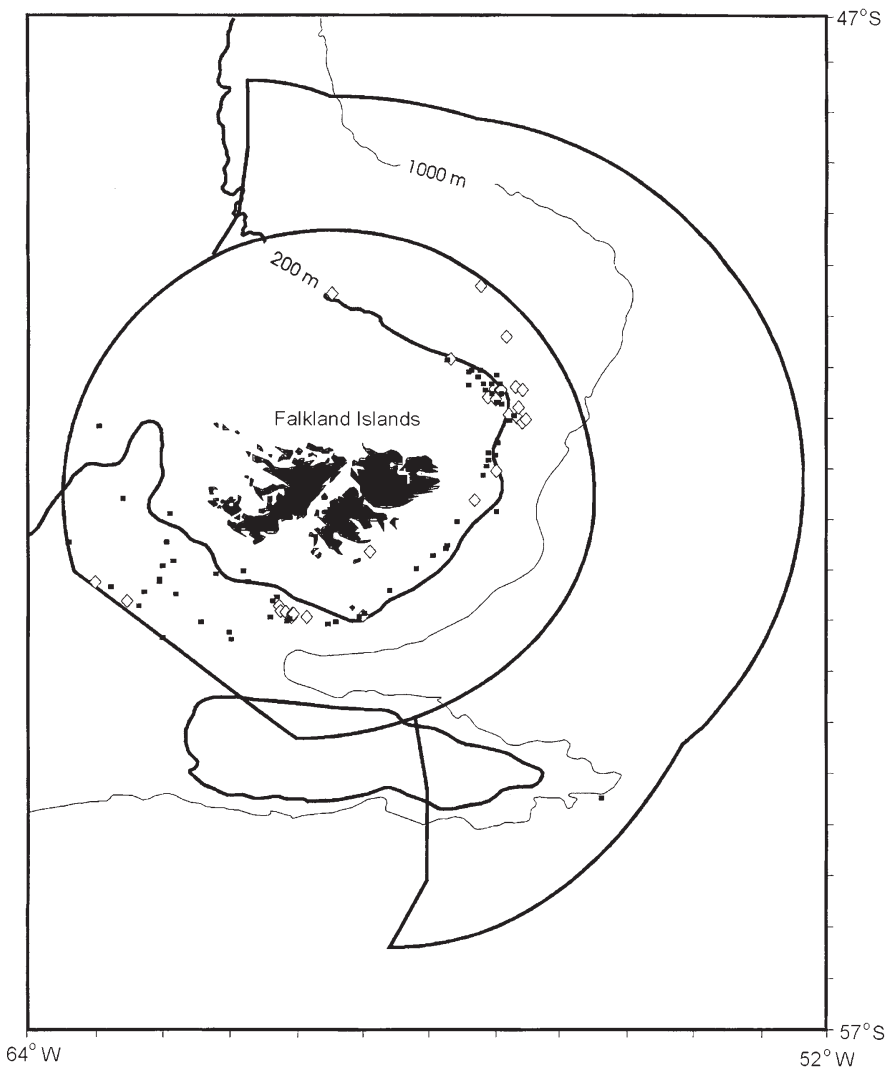

Fig. 1. Collection locations for all Lampris immaculatus in this study. Squares are locations where individuals were captured and stomachs were collected for analysis; diamonds are locations where individuals were captured, but stomach contents were not collected. The 2 regions delineated in dark lines represent the Falkland Islands Interim Conservation and Management Zone (FICZ), and the Falklands Outer Conservation Zone (FOCZ)

Whole animals were measured to the nearest $\mathrm{mm}$, dorsal ML for squid and total length (TL) for fish. The hard parts which remained after all whole animals had been measured were re-examined for identification of the components of each group. These parts, including beaks and hooks of squid, and otoliths, scales and bones from fish, and were identified using reference specimens held at FIFD and by reference to Clarke (1986) and Hecht (1987). The rostral lengths of dried beaks and total length of otoliths were measured to the nearest $0.1 \mathrm{~mm}$ using vernier calipers and a dissecting microscope fitted with an eye-piece graticule. Total squid number was determined by adding whole animals with beak numbers. To determine the number of fish represented by the otoliths, all otoliths for each species were examined and recorded whether left or right. Total fish represented by otoliths were therefore taken as the greatest number of either left or right otoliths. This number was then added to the number of intact ingested fish. 
Table 1. Regression equations between total length (TL) and otolith length (OL) and weight (W) and OL for the 2 common fish prey species from field captured specimens used to reconstruct prey size from ingested otoliths in the stomach of Lampris immaculatus

\begin{tabular}{|llcc|}
\hline Species & Equation & $\mathrm{n}$ & $\mathrm{r}^{2}$ \\
\hline Gymnoscopelus nicholsi & $\operatorname{lnTL}=1.09 \operatorname{lnOL}+3.17$ & 214 & 0.94 \\
& $\ln \mathrm{W}=3.47 \operatorname{lnOL}-2.86$ & 214 & 0.94 \\
Micromesistius australis & $\operatorname{lnTL}=1.37 \operatorname{lnOL}+2.39$ & 449 & 0.99 \\
& $\ln \mathrm{W}=3.97 \operatorname{lnOL}-4.54$ & 449 & 0.99 \\
\hline
\end{tabular}

Some lengths for fish (TL) and squid (ML) were taken directly from ingested individuals that were in a relatively intact state. Length and weight of other individuals were reconstructed from either beaks or otoliths. Length and weight (W) for Moroteuthis ingens were determined from beak regressions from Jackson et al. (1997). However, weights for intact ingested individuals were determined from lengths using lengthweight regressions for $M$. ingens in the Falkland Islands region captured previously (Jackson unpubl. data). Reconstructed lengths for Loligo gahi beaks were determined from beak-ML regressions provided by $\mathrm{E}$. Hatfield (unpubl. data). The reconstructed fish TL and W were calculated from otolith length-fish length regressions from known individuals of Gymnoscopelus nicholsi and Micromesistius australis in this study (Table 1). The specimen weight for ingested individuals of these 2 fish species were calculated from lengthweight regressions from field captured fish, as individual prey weights were not taken. Only the otoliths in the best condition (i.e. not chipped and not eroded) were used for estimating fish TL and W. These non-eroded otoliths from $G$. nicholsi and $M$. australis were 46.2 and $51.2 \%$ of total otolith number, respectively. The TL and W data obtained from these otoliths were then scaled to $50 \%$ (i.e. representing total fish number since otoliths are paired). This data was then used for calculating biomass and length frequency for each species.

\section{RESULTS}

There were 133 positive records for Lampris immaculatus from the observer program of the Falkland Islands Government Fisheries Department from 1990 to 1995. All records of occurrences were made between July and January with most records during the month of October. The timing of these records is directly correlated with the pelagic fishery for blue whiting. We therefore do not have access to samples from other times of the year. It is probable that $L$. immaculatus is abundant throughout the year as specimens are caught whenever fishing operations take place. The majority of individuals were caught around the $200 \mathrm{~m}$ depth contour in waters close to the Falkland Islands where much of the commercial fishing takes place (Fig. 1).

During 1993-1994, 69 fish (50 females, 7 males and 12 unsexed) were collected from 28 stations and their stomachs removed for diet studies. Lampris immaculatus is a large fish with individuals measured in this study ranging from 72 to $142 \mathrm{~cm}$ TL (Fig. 2).

The diet of Lampris immaculatus (Table 2) was dominated by 4 species (2 squid and 2 fish). A large number of these prey were identified from only otolith or beak remains (Table 3). The onychoteuthid squid Moroteuthis ingens was the most abundant prey item and occurred in $93 \%$ of the stomachs examined and was represented by 644 individuals either as whole individuals or beaks. In a number of instances, the stomach was packed tightly with predominantly $M$. ingens (Fig. 3). The second most important prey was the loliginid squid Loligo gahi (23\% of stomachs, 309 individuals). The 2 common fish prey were the myctophid Gymnoscopelus nicholsi (42\% of stomachs, 292 individuals) and the southern blue whiting Micromesistius australis ( $23 \%$ of stomachs, 70 individuals). Three of the southern blue whiting ingested appeared to be scavenged from fishing boat discards. In one instance, the prey consisted of a fish frame which had been filleted. There were also 3 records of very freshly ingested $M$. australis, which probably represented net feeding. An interesting finding was the relatively high occurrence of anthropogenic waste (plastic) which was present in the stomachs of 10 fish ( $14 \%$ of total). The other prey, at least 6 fish species and 2 squid species were relatively uncommon and occurred in no more than $7 \%$ of stomachs and less than 10 individuals.

Loligo gahi had the greatest proportion of individuals $(58.3 \%)$ relatively undigested. The greatest proportion (54.5 to $60 \%$ ) of the other 3 common prey species (Moroteuthis ingens, Gymnoscopelus nicholsi, and Micromesistius australis) were digestion stage 5 and rep-

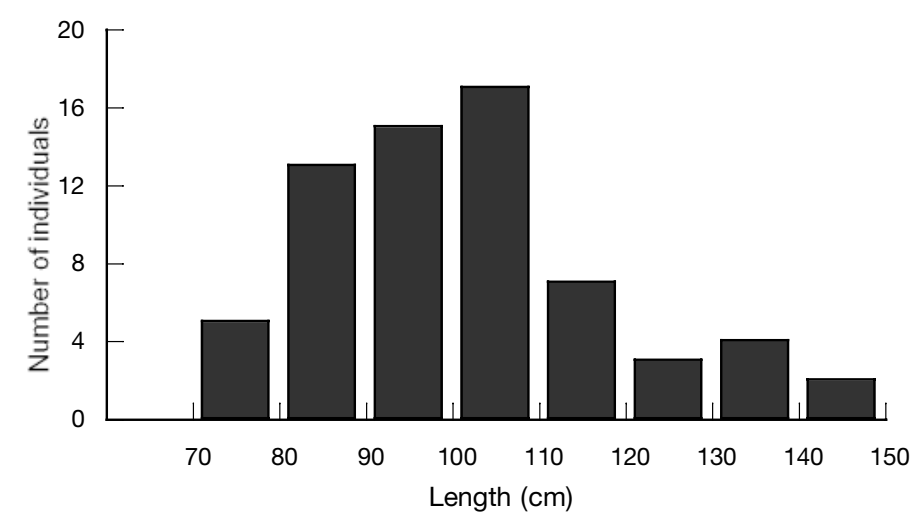

Fig. 2. Lengths of Lampris immaculatus which were measured $(\mathrm{n}=66)$ 
Table 2. Numbers of prey species and plastic in stomachs of Lampris immaculatus. na: not applicable

\begin{tabular}{|c|c|c|c|c|c|c|c|}
\hline Species & $\begin{array}{c}\text { No. } \\
\text { of stomachs } \\
(n=69)\end{array}$ & $\begin{array}{c}\text { Percent } \\
\text { occurrence } \\
\text { in total } \\
\text { stomachs }\end{array}$ & $\begin{array}{c}\text { No. } \\
\text { of prey } \\
(\mathrm{n}=1370)\end{array}$ & $\begin{array}{c}\text { Percentage } \\
\text { of total } \\
\text { prey }\end{array}$ & $\begin{array}{l}\text { Range } \\
\text { prey items } \\
\text { per } \\
\text { stomach }\end{array}$ & $\begin{array}{l}\text { Average } \\
\text { prey items } \\
\text { per } \\
\text { stomach }\end{array}$ & $\begin{array}{c}\text { SD } \\
\text { prey items } \\
\text { per } \\
\text { stomach }\end{array}$ \\
\hline \multicolumn{8}{|l|}{ Gadidae (cods) } \\
\hline Micromesistius australis & 16 & 23.2 & 70 & 5.1 & $1-31$ & 4 & 8.7 \\
\hline \multicolumn{8}{|l|}{ Myctophiodae (lanternfishes) } \\
\hline Electrona carlsbergi & 1 & 1.4 & 1 & 0.1 & $1-1$ & 1 & na \\
\hline Electrona subaspera & 5 & 7.2 & 6 & 0.4 & $1-2$ & 1 & 0.5 \\
\hline Electrona, unidentified & 2 & 2.9 & 2 & 0.1 & $1-1$ & 1 & 0 \\
\hline Gymnoscopelus bolini & 1 & 1.4 & 1 & 0.1 & $1-1$ & 1 & na \\
\hline Gymnoscopelus nicholsi & 29 & 42.0 & 292 & 21.3 & $1-51$ & 10 & 12.0 \\
\hline Gymnoscopelus, unidentified & 2 & 2.9 & 3 & 0.2 & $1-2$ & 2 & 0.7 \\
\hline Protomyctophum choriodon & 2 & 2.9 & 2 & 0.1 & $1-1$ & 1 & 0 \\
\hline Myctophid, unidentified & 3 & 4.3 & 10 & 0.7 & $1-5$ & 3 & 2.1 \\
\hline \multicolumn{8}{|l|}{ Moridae (deepsea cods) } \\
\hline Notothenid, unidentified & 1 & 1.4 & 8 & 0.6 & $1-1$ & 1 & na \\
\hline Fish, unidentified & 2 & 2.9 & 2 & 0.1 & $1-1$ & 1 & 0 \\
\hline \multicolumn{8}{|l|}{ Onychoteuthidae } \\
\hline Moroteuthis ingens & 64 & 92.8 & 644 & 47.0 & $1-48$ & 10 & 9.1 \\
\hline \multicolumn{8}{|l|}{ Loliginidae } \\
\hline Loligo gahi & 16 & 23.2 & 309 & 22.6 & $1-65$ & 18 & 18.6 \\
\hline \multicolumn{8}{|l|}{ Ommastrephidae } \\
\hline Martialia hyadesi & 3 & 4.3 & 3 & 0.2 & $1-1$ & 1 & 0 \\
\hline \multicolumn{8}{|l|}{ Gonatidae } \\
\hline Gonatus antarcticus & 1 & 1.4 & 1 & 0.1 & $1-1$ & 1 & na \\
\hline Isopod, unidentified & 1 & 1.4 & 1 & 0.1 & $1-1$ & 1 & na \\
\hline Anthropogenic waste (plastic) & 10 & 14.5 & 10 & 0.7 & $1-1$ & 1 & 0 \\
\hline Unknown & 5 & 7.2 & 5 & 0.4 & $1-1$ & 1 & 0 \\
\hline
\end{tabular}

Table 3. Numbers of beaks and otoliths present in stomachs of Lampris immaculatus used in prey size reconstruction. Intact otoliths refer to the otoliths that were in good condition and used in reconstruction

\begin{tabular}{|c|c|c|c|c|c|c|c|c|}
\hline Species & $\begin{array}{c}\text { No. of } \\
\text { beaks } \\
(\mathrm{n}=534)\end{array}$ & $\begin{array}{c}\text { Percentage } \\
\text { of total } \\
\text { beaks }\end{array}$ & $\begin{array}{c}\text { No. of } \\
\text { otoliths } \\
(\mathrm{n}=407)\end{array}$ & $\begin{array}{c}\text { Percentage } \\
\text { of total } \\
\text { otoliths }\end{array}$ & $\begin{array}{l}\text { Percent of } \\
\text { otoliths } \\
\text { intact }\end{array}$ & $\begin{array}{l}\text { Range in } \\
\text { otolith length } \\
\quad(\mathrm{mm})\end{array}$ & $\begin{array}{l}\text { Mean otolith } \\
\text { length } \\
(\mathrm{mm})\end{array}$ & $\mathrm{SD}$ \\
\hline \multicolumn{9}{|l|}{ Gadidae (cods) } \\
\hline Micromesistius australis & - & - & 84 & 20.6 & 51.2 & $6.7-16.5$ & 11.1 & 2.8 \\
\hline \multicolumn{9}{|l|}{ Myctophiodae (lanternfishes) } \\
\hline Electrona carlsbergi & - & - & 1 & 0.2 & 100 & $2.6-2.6$ & 2.6 & na \\
\hline Electrona subaspera & - & - & 9 & 2.2 & 75 & $2.0-4.1$ & 3.2 & 0.9 \\
\hline Electrona, unidentified & - & - & 4 & 1.0 & 100 & $2.8-2.9$ & 2.9 & 0.1 \\
\hline Gymnoscopelus bolini & - & - & 0 & 0 & na & na & na & na \\
\hline Gymnoscopelus nicholsi & - & - & 305 & 74.9 & 46.2 & $2.5-5.3$ & 3.9 & 0.6 \\
\hline Gymnoscopelus, unidentified & - & - & 4 & 1.0 & 100 & $3.1-3.3$ & 3.2 & 0.1 \\
\hline Protomyctophum choriodon & - & - & 0 & 0 & na & na & na & na \\
\hline Myctophid, unidentified & - & - & 0 & 0 & na & na & na & na \\
\hline \multicolumn{9}{|l|}{ Moridae (deepsea cods) } \\
\hline Notothenid, unidentified & - & - & 0 & 0 & na & na & na & na \\
\hline Fish, unidentified & - & - & 0 & 0 & na & na & na & na \\
\hline \multicolumn{9}{|l|}{ Onychoteuthidae } \\
\hline Moroteuthis ingens & 479 & 89.7 & - & - & - & - & - & - \\
\hline \multicolumn{9}{|l|}{ Loliginidae } \\
\hline Loligo gahi & 52 & 9.7 & - & - & - & - & - & - \\
\hline \multicolumn{9}{|l|}{ Ommastrephidae } \\
\hline Martialia hyadesi & 2 & 0.4 & - & - & - & - & - & - \\
\hline \multicolumn{9}{|l|}{ Gonatidae } \\
\hline Gonatus antarcticus & 1 & 0.2 & - & - & - & - & - & - \\
\hline
\end{tabular}




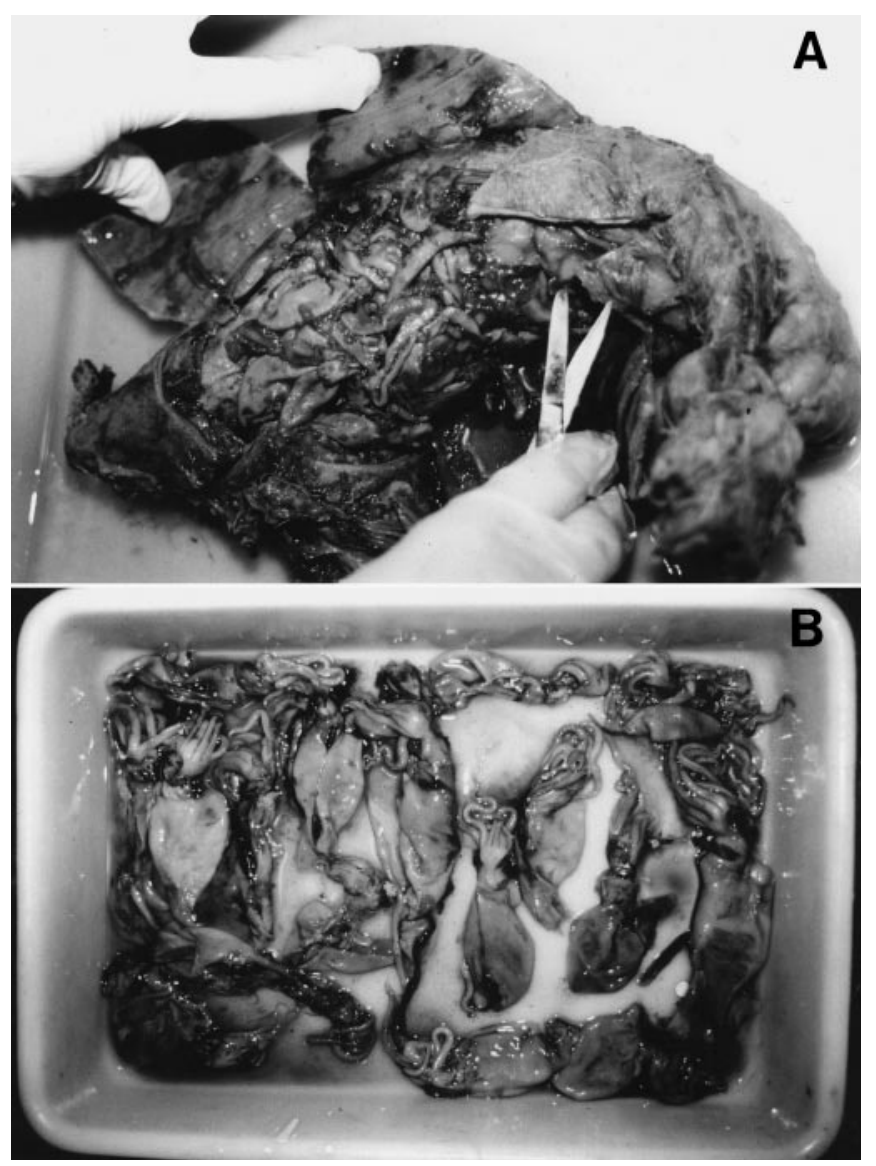

Fig. 3. Stomach content analysis from a single Lampris immaculatus individual showing (A) the stomach being dissected, packed with squid and (B) the contents spread out showing the numerous ingested individuals of Moroteuthis ingens resented only by otoliths and beaks (Table 4). It is interesting to note that only 14 of the 644 individuals of $M$. ingens ingested were freshly eaten (stage 1). This is comparable to the second most important prey, L. gahi, in which 180 of the 309 individuals ingested were recently eaten.

The majority of Moroteuthis ingens ingested ranged from $50.5 \mathrm{~mm} \mathrm{ML} \mathrm{(4.5} \mathrm{g)} \mathrm{to} 195 \mathrm{~mm} \mathrm{ML}$ (235.5 g) (Fig. 4A,B). However, 3 very large squid were ingested with MLs and weights of $255 \mathrm{~mm}$ (543 g), $268.5 \mathrm{~mm}$ (645 g) and $406 \mathrm{~mm}$ (2275 g). The sizes of these 3 very large individuals were reconstructed from beak lengths. These 3 squid may represent feeding on heads or buccal masses possibly as a result of net damaged squid from trawling operations. The modal size of squid ingested was 120 to $130 \mathrm{~mm} \mathrm{ML} \mathrm{(60} \mathrm{to} 70 \mathrm{~g}$ ) and, except for the 3 large individuals, all were less than $200 \mathrm{~mm} \mathrm{ML}$ and $260 \mathrm{~g}$, with an average weight of $69 \mathrm{~g}$. The majority of $M$. ingens were between 100 and $150 \mathrm{~mm}$ ML and 20 and $120 \mathrm{~g}$.

Both beaks and whole individuals of Loligo gahi were found in the Lampris immaculatus stomachs. Individual size (both directly measured and reconstructed from beaks) ranged from 51 to $207 \mathrm{~mm}$ ML (n = 304) (Fig. 5).

The fish prey size was directly measured or reconstructed using regressions from field-captured fish (Table 1) from otoliths for the 2 most abundant fish, Gymnoscopelus nicholsi and southern blue whiting Micromesistius australis. G. nicholsi ranged from $45 \mathrm{~mm}(0.5 \mathrm{~g})$ to $150 \mathrm{~mm}(20 \mathrm{~g})$ with a modal length frequency of 110 to $120 \mathrm{~g}$ and a modal

Table 4. Numbers and percentages (in parentheses) for each prey species in each digestion stage

\begin{tabular}{|c|c|c|c|c|c|c|c|c|}
\hline \multirow[t]{2}{*}{ Code } & \multicolumn{7}{|c|}{ Digestion stage } & \multirow[t]{2}{*}{ Total } \\
\hline & 0 & 1 & 2 & 3 & 4 & 5 & 6 & \\
\hline Micromesistius australis & & $12(17.1)$ & $10(14.3)$ & $4(5.7)$ & $2(2.9)$ & $42(60.0)$ & & 70 \\
\hline Electrona carlsbergi & & & & & & $1(100)$ & & 1 \\
\hline Electrona subaspera & & & & & & $6(100)$ & & 6 \\
\hline Electrona, unidentified & & & & & & $2(100)$ & & 2 \\
\hline Gymnoscopelus bolini & & $1(100)$ & & & & & & 1 \\
\hline Gymnoscopelus nicholsi & & $111(38.0)$ & $4(1.4)$ & $8(2.7)$ & $10(3.4)$ & $159(54.5)$ & & 292 \\
\hline Gymnoscopelus, unidentified & & $1(33.3)$ & & & & $2(66.7)$ & & 3 \\
\hline Protomyctophum choriodon & & & & $2(100)$ & & & & 2 \\
\hline Myctophid, unidentified & & & & $1(10.0)$ & $9(90.0)$ & & & 10 \\
\hline Notothenid, unidentified & & $8(100)$ & & & & & & 8 \\
\hline Fish, unidentified & & & & & $2(100)$ & & & 2 \\
\hline Moroteuthis ingens & & $14(2.2)$ & $77(12.0)$ & $117(18.2)$ & $56(8.7)$ & $376(58.4)$ & $4(0.6)$ & 644 \\
\hline Loligo gahi & & $180(58.3)$ & $49(15.9)$ & $29(9.4)$ & $1(0.3)$ & $50(16.2)$ & & 309 \\
\hline Martialia hyadesi & & & & $1(33.3)$ & & $2(66.7)$ & & 3 \\
\hline Gonatus antarcticus & & & & & & $1(100)$ & & 1 \\
\hline Isopod, unidentified & & & $1(100)$ & & & & & 1 \\
\hline Anthropogenic waste (plastic) & $10(100)$ & & & & & & & 10 \\
\hline Unknown & & $3(60.0)$ & & & $1(20.0)$ & $1(20.0)$ & & 5 \\
\hline
\end{tabular}



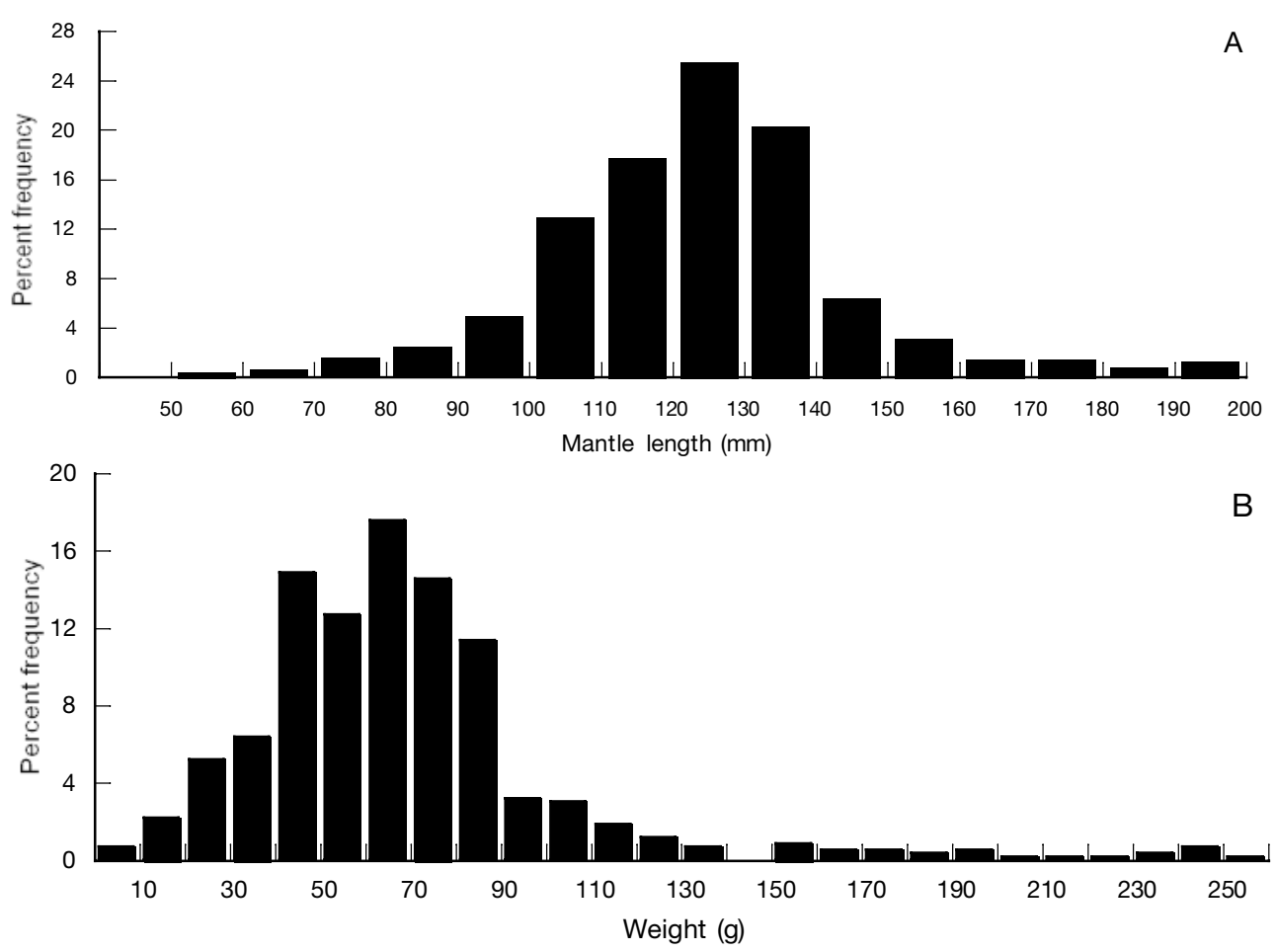

Fig. 4. Mantle length and weight distributions for prey species Moroteuthis ingens $(\mathrm{n}=599)$ reconstructed from whole individuals and intact beaks removed from the stomachs of Lampris immaculatus $(\mathrm{n}=64)$

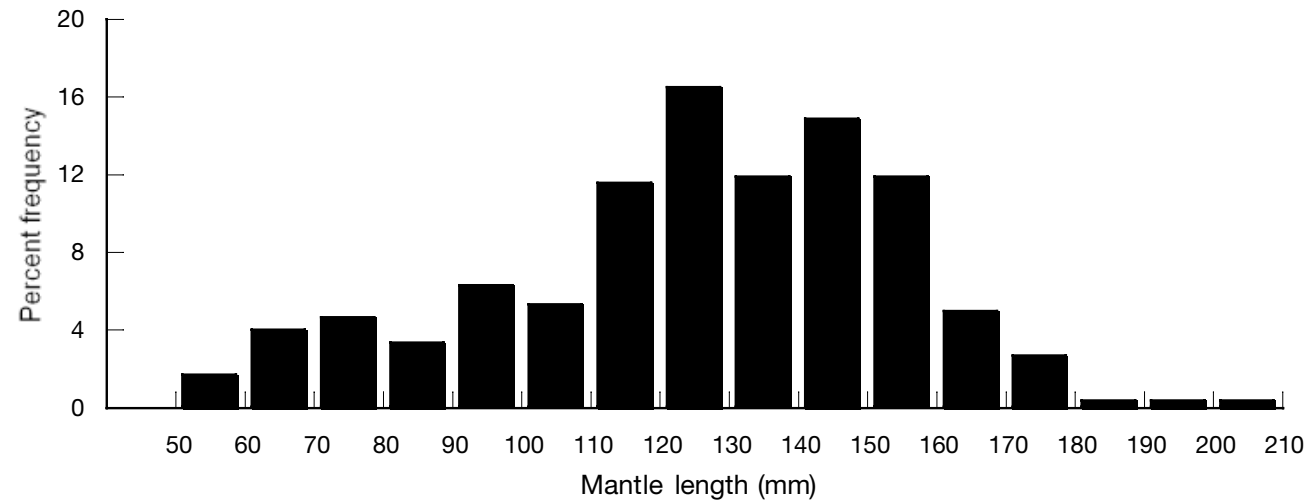

Fig. 5. Mantle length distribution for prey species Loligo gahi $(\mathrm{n}=304)$ reconstructed from whole individuals and intact beaks removed from the stomachs of Lampris immaculatus $(\mathrm{n}=16)$

weight of 7 to $8 \mathrm{~g}, \mathrm{n}=262$ (Fig. 6A,B). M. australis ranged in size from $148 \mathrm{~mm}(21 \mathrm{~g})$ to $508 \mathrm{~mm}(727 \mathrm{~g})$, $\mathrm{n}=63$. There was a spread of lengths and weights without any clear modal size range (Fig. 7A,B). The average weight of $G$. nicholsi and $M$. australis ingested was 10 and $257 \mathrm{~g}$ respectively.

There was no clear relationship between the size of the 4 main prey species (Moroteuthis ingens, Loligo gahi, Micromesistius australis, Gymnoscopelus nicholsi) and the size of Lampris immaculatus (Fig. 8A to D). There was no obvious trend of larger fish ingesting larger prey. L. immaculatus appears to ingest juvenile
$M$. ingens of a fairly narrow size range (Fig. 8A). Similarly, larger individuals of $M$. australis are predominantly eaten, except for 2 large $L$. immaculatus that ingested a number of $M$. australis covering a wide size range (Fig. 8B).

The ingested plastic appeared to come from a variety of sources and included predominantly food-associated items (such as potato chip, frozen fish and napkin packets). In some instances, the country of origin could be determined. The other identifiable items included a cigarette box wrapping and various unidentified plastic strips, sheets and lines (Table 5). The strips were the 

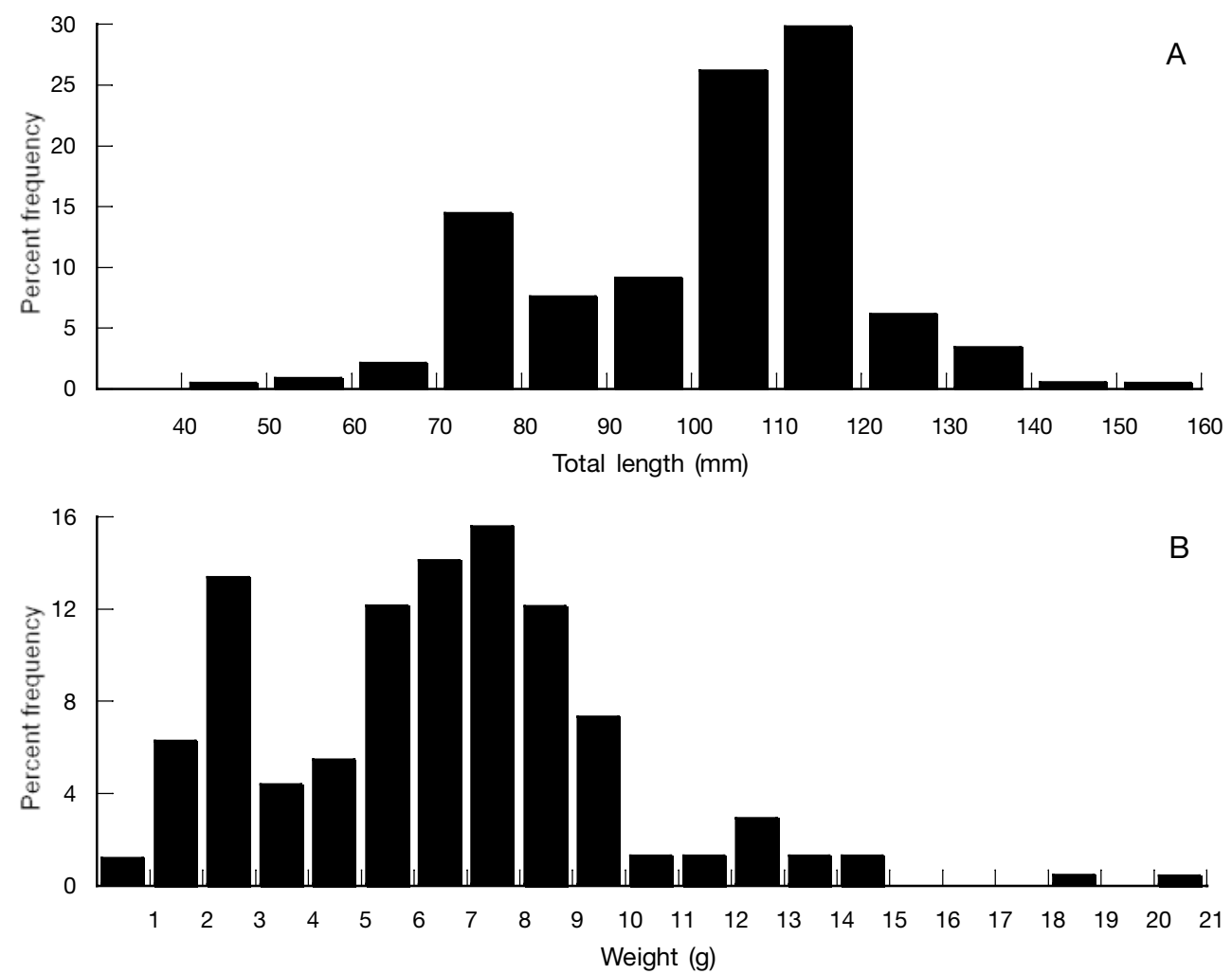

Fig. 6. Estimated length and weight distributions for all Gymnoscopelus nicholsi consumed. Reconstructed from whole individuals and the lengths of intact otoliths removed from the stomachs of Lampris immaculatus
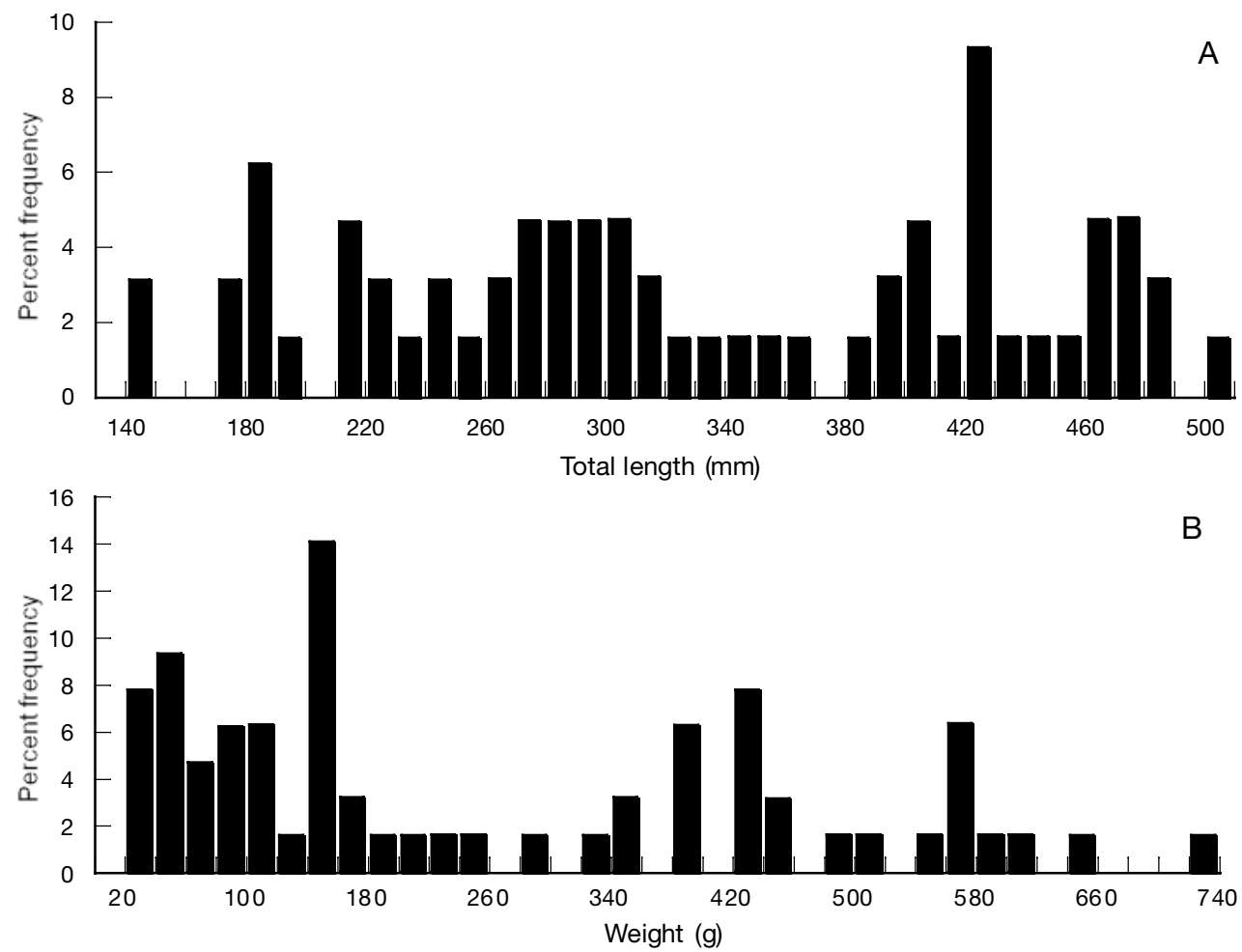

Fig. 7. Estimated length and weight distributions for all Micromesistus australis consumed. Reconstructed from whole individuals and the lengths of intact otoliths removed from the stomachs of Lampris immaculatus 

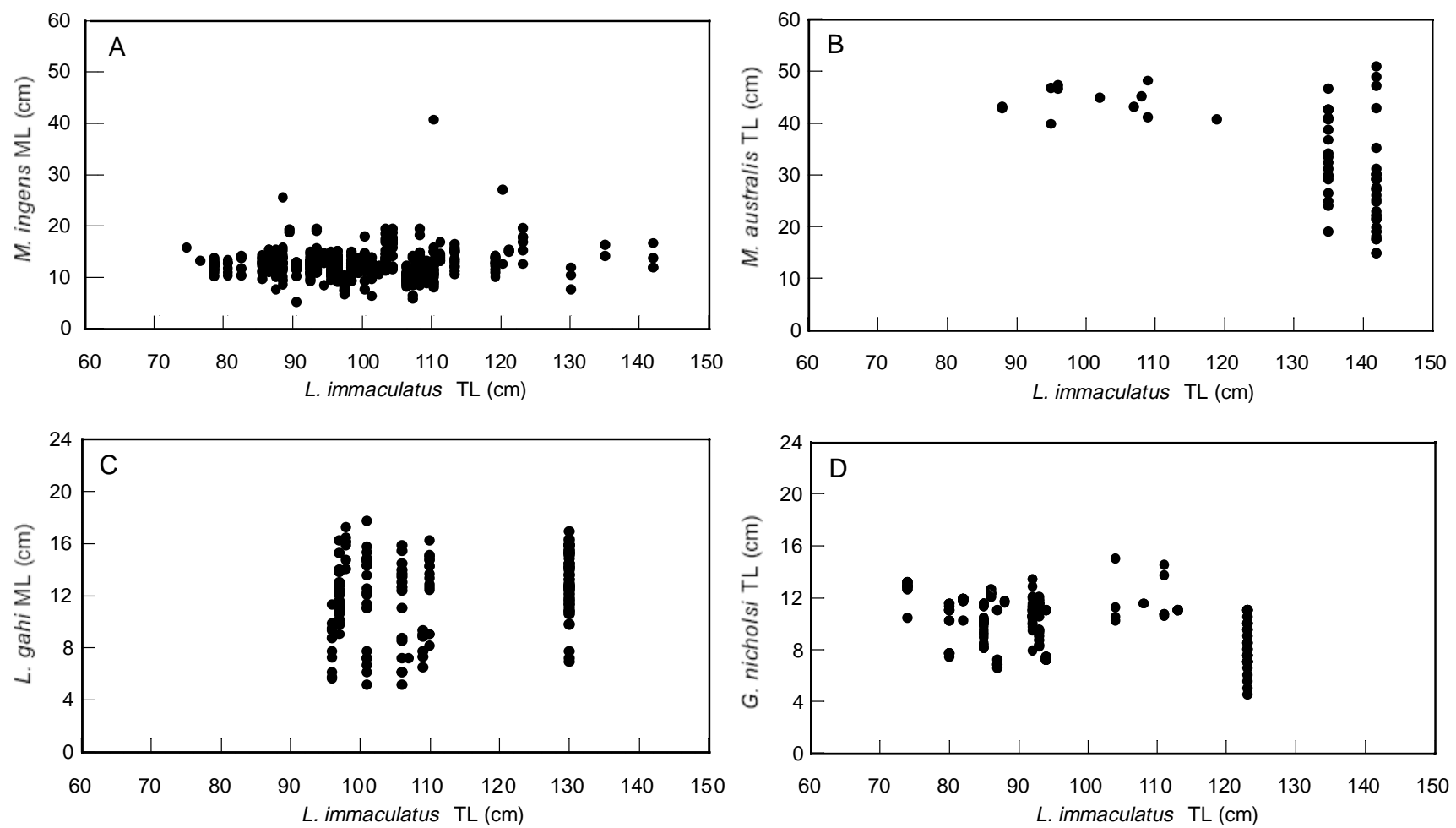

Fig. 8. Size relationship between Lampris immaculatus and its prey (A) Moroteuthis ingens (B) Micromesistus australis (C) Loligo gahi (D) Gymnoscopelus nicholsi; TL = total length, ML = mantle length

Table 5. Details of plastic found in stomachs of Lampris immaculatus individuals

\begin{tabular}{|lclrl|}
\hline $\begin{array}{l}\text { Specimen } \\
\text { number }\end{array}$ & $\begin{array}{c}\text { Fish length } \\
(\mathrm{TL})\end{array}$ & $\begin{array}{l}\text { Date of } \\
\text { capture }\end{array}$ & $\begin{array}{l}\text { Weight of } \\
\text { plastic }(\mathrm{g})\end{array}$ & Comments \\
\hline 5 & 104 & 19 Oct 94 & 6.70 & Thin translucent strip of plastic $(28.5 \times 13.5 \mathrm{~cm})$ \\
20 & 93 & 22 Oct 94 & 11.70 & 1 piece mono-filament line $(6 \mathrm{~cm})$ \\
26 & 80 & 23 Oct 94 & 1.50 & 1 cigarette packet wrapper \\
27 & 88 & 23 Oct 94 & 27.00 & Spanish 'Felipita' super-absorbent napkin wrapper $(19.5 \times 18 \mathrm{~cm})$ \\
42 & 95 & 25 Oct 94 & 5.90 & Thin, translucent strip of plastic $(67.5 \times 4.5 \mathrm{~cm})$ \\
49 & - & 21 Aug 94 & 6.00 & 1 piece polythene, not measured \\
62 & - & 21 Oct 94 & 13.00 & Frozen fish packed from Chile, imported to USA $(28 \times 36 \mathrm{~cm})$ \\
64 & - & 21 Oct 94 & 5.00 & Thick plastic sheet $(10 \times 13 \mathrm{~cm})$ \\
66 & 121 & 10 Sep 94 & 14.00 & Bluebird crisp packet - New Zealand $(16 \times 20 \mathrm{~cm})$ \\
68 & 135 & 26 Oct 95 & 0.10 & 1 piece clear wrapping plastic $(2.5 \times 1.5 \mathrm{~cm})$ \\
\hline
\end{tabular}

type used in securing cardboard boxes on board fishing vessels. In some instances, the sizeable pieces of plastic hindered digestion as some of the ingested prey were surrounded by the plastic and were relatively hard, dried and undigested.

\section{DISCUSSION}

Fish stomach content analysis continues to be an important mechanism for understanding feeding ecology and a means to explore interactions between predators and prey (Hall et al. 1995). The dietary analysis of Lampris immaculatus has provided information on aspects of the feeding ecology of this fish as well as insights on its feeding behaviour and habitat. Earlier work on cephalopod remains in blue shark Prionace glauca stomachs has been used to infer migration from deeper oceanic waters to shallower near shore waters of the English Channel (Stevens 1973, Clarke \& Stevens 1974). While many fish appear to have a diverse diet, there is evidence of some species feeding predominantly on cephalopods. The swordfish Xiphias gladius appears to also consume predominantly cephalopods (particularly 
squids) with the genus Illex being the most important prey in the Florida Straits (Toll \& Hess 1981) and also an important prey item in this species in the Mediterranean (Moreira 1990). A number of pelagic fish include cephalopods in their diet and such fish may serve as useful sampling devices for determining occurrence and seasonal patterns of squids which are difficult or expensive to collect otherwise (Smale 1996).

Lampris immaculatus is regularly encountered on the Patagonian shelf and, although not an abundant species, it is probably not as rare as suggested in earlier reports (Heemstra 1986) and may be even more abundant in pelagic waters. It is interesting that Moroteuthis ingens makes up such a significant part of the diet of this pelagic fish. Although $M$. ingens is present on the Patagonian Shelf (Jackson 1998a), based on observer records, it is not nearly as abundant as other species such as Loligo gahi or Micromesistius australis, which are caught by the tonne by commercial fisheries.

The significance of Moroteuthis ingens in the marine ecosystem is gradually being revealed by ongoing research. This squid is an active predator of myctophids and other meso-pelagic fish in New Zealand (Jackson et al. 1998b). It is in turn preyed upon by a number of predators including at least 4 mammals, 17 birds, 13 fish and 1 squid species. It is also cannibalistic (Jackson et al. 1998a). Information from the diet of Lampris immaculatus in this study suggests that juveniles of $M$. ingens may also be common in open pelagic waters since this fish is a pelagic predator. This agrees with earlier work suggesting that although the adults of $M$. ingens are demersal, the juveniles are pelagic (Jackson 1993). Cherel \& Weimerskirch (1999) have also shown that pelagic feeding king penguins also target juvenile $M$. ingens in the Crozet Islands region. The fact that both the pelagic $L$. immaculatus and king penguins feed on large numbers of juvenile individuals of $M$. ingens provides evidence for an epipelagic habitat for juveniles of this squid.

Our diet analysis could be biased due to some prey items being secondarily ingested in stomachs of the ingested prey. The fact that both Moroteuthis ingens (Jackson 1998b) and Micromesistius australis (Laptikhovsky \& Fetisov 1999) are known to prey on myctophids could suggest that some of the Gymnoscopelus nicholsi otoliths recovered could have been originally ingested by either of these 2 species. However, this is not necessarily the case as there were a substantial number of ingested fish that were intact and relatively undigested within the stomachs of Lampris immaculatus. However, it is likely that the otoliths from the very small individuals of $G$. nicholsi were a result of secondary ingestion. Currently it is difficult to assess the percentage of the diet which might be secondarily ingested.
The presence of remains of Micromesistius australis, which were apparently scavenged from fishing vessel discards, is interesting. This suggests that Lampris immaculatus is actively foraging in the vicinity of fishing vessels. Laptikhovsky \& Fetisov (1999) found that discarded squid remains from the Patagonian squid fishery represented between 20 and $40 \%$ of diets of 3 fish species (Merluccius hubbsi, Patagononotothen ramsayi, Macrourus holotrachys) on the Patagonian Shelf. Such levels of discard feeding were suggested to possibly affect trophic interactions within this ecosystem. Fishing activity may therefore be modifying the feeding behaviour of $L$. immaculatus as well.

The plastic ingested by Lampris immaculatus is noteworthy, especially given the variety that was eaten. Furthermore, this study suggests that it is not just an incidental occurrence since $14 \%$ of the fish had some form of plastic in their stomachs. Plastic, metal and other non-food objects are a common occurrence in the stomachs of some shark species (Wetherbee et al. 1990), but we are not familiar with such high levels of plastic recorded for a teleost. Ingested plastic in marine organisms has been found to block digestive tracts, damage stomach linings and lessen feeding drives (Laist 1987). The full impact of plastic on this species is currently unknown, but is likely to include the above problems. Given the abundance and diversity of plastic ingested, it appears that L. immaculatus may be confusing it with prey.

This is not the first study to highlight the impact of plastic debris in the Southern Ocean. Plastic has also been shown to be significant in the diet of Antarctic petrels (van Franeker \& Bell 1988). Moreover, Croxall et al. (1990) found that Antarctic fur seals at South Georgia had significant levels of entanglement by man-made debris, including polypropylene packaging bands, which are also ingested by Lampris immaculatus. Internationally, plastic pollution continues to be an increasing problem in the marine environment (Pruter 1987, Wolfe 1987). Undertaking a more comprehensive study of the diet of L. immaculatus from different sectors of the Southern Ocean could reveal the impact of marine plastic pollution on a more global level.

Stomach content analysis continues to be a useful means to address the feeding behaviour of a marine organism which is difficult to observe (Hyslop 1980, Hall et al. 1995). This study has provided an intriguing insight into the feeding biology of a large pelagic fish that has rarely been encountered in the past. It appears that the plastic ingested originates from fishing vessel discards and Lampris immaculatus may even be following fishing vessels. More careful monitoring of plastic pollution in the Southern Ocean by national and international bodies needs to be carried out in the future. 
Acknowledgements. We would like to acknowledge support given by the Falkland Islands Government Fisheries Department and Fisheries Department observers to this project. Travel support of the Falkland Islands for G.D.J. was provided by the Ian Potter/George Alexander Foundation and by Peter and Patrick Davy of Stevedore and Fishery Services Ltd. and is greatly appreciated. We appreciate the help of Dick Williams, who assisted with otolith identification, Julian Finn and Jacqui Parker, who assisted with data analysis and figure preparation, Emma Hatfield, who provided unpublished beak regressions for Loligo gahi, and John Barton and Alexander Arkhipkin, who made helpful comments on the manuscript.

\section{LITERATURE CITED}

Arkhipkin AI, Bizikov VA (1991) Comparative analysis of age and growth rates estimation using statoliths and gladius in squids. In: Jereb P, Ragonese S, Boletzky SV (eds) Squid age determination using statoliths. Proceedings of an International Workshop, 9-14 Oct 1989, Mazara del Vallo, Italy. Istituto di Technologia della Pesca e del Pescato, Mazara del Vallo. Spec Publ 1. N.T.R.-I.T.P.P., p 19-33

Bello G (1991) Role of cephalopods in the diet of the swordfish, Xiphias gladius, from the eastern Mediterranean Sea. Bull Mar Sci 1-2:312-324

Cherel Y, Weimerskirch H (1999) Spawning cycle of onychoteuthid squids in the southern Indian Ocean: new information from seabird predators. Mar Ecol Prog Ser 188:93-104

Cherel Y, Verdon C, Ridoux V (1993) Seasonal importance of oceanic myctophids in king penguin diet at Crozet Islands. Polar Biol 13:355-357

Cherel Y, Ridoux V, Rodhouse PG (1996) Fish and squid in the diet of king penguin chicks, Aptenodytes patagonicus, during winter at subantarctic Crozet Islands. Mar Biol 126: $559-570$

Clarke MR (1986) A handbook for the identification of cephalopod beaks. Clarendon Press, Oxford

Clarke MR, Stevens JD (1974) Cephalopods, blue sharks and migration. J Mar Biol Assoc UK 54:949-957

Croxall JP, Rodwell S, Boyd IL (1990) Entanglement in manmade debris of Antarctic fur seals at Bird Island, South Georgia. Mar Mamm Sci 6:221-233

Dunning MC, Clarke MR, Lu CC (1993) Cephalopods in the diet of oceanic sharks caught off eastern Australia. In: Okutani T, O'Dor RK, Kubodera T (eds) Recent advances in cephalopod fisheries biology. Tokai University Press, Tokyo, p 119-131

Ebert DA, Compagno LJV, Cowley PD (1992) A preliminary investigation of the feeding ecology of squaloid sharks off the west coast of Southern Africa. S Afr J Mar Sci 12:601-609

Gon O (1990) Lampridae. In: Gon O, Heemstra PC (eds) Fishes of the Southern Ocean. JLB Smith Institute of Ichthyology, Grahamstown

Green K, Burton HR (1993) Comparison of the stomach contents of southern elephant seals, Mirounga leonina, at Macquarie and Heard Islands. Mar Mamm Sci 9:10-22

Guerra A, Simon F, Gonzalez AF (1993) Cephalopods in the diet of the swordfish, Xiphias gladius, from the northeastern Atlantic Ocean. In: Okutani T, O'Dor RK, Kubodera T (eds) Recent advances in cephalopod fisheries biology. Tokai University Press, Tokyo, p 159-164

Hall SJ, Gurney WSC, Dobby H, Basford DJ, Heaney SD, Robertson MR (1995) Inferring feeding patterns from stomach contents data. J Anim Ecol 64:39-62

Hecht T (1987) A guide to the otoliths of Southern Ocean fishes. S Afr J Antarct Res 17(1):1-87
Heemstra PC (1986) Lampridae. In: Smith MM, Heemstra PC (eds) Smiths's sea fishes. JLB Smith Institute of Ichthyology, Grahamstown, p 398

Hyslop EJ (1980) Stomach content analysis - a review of methods and their application. J Fish Biol 17:411-429

Imber MJ (1991) Feeding ecology of antarctic and sub-antarctic procellariiformes. Acta XX Congr Int Ornithol 3:1402-1412

Jackson GD (1993) Growth zones within the statolith microstructure of the deepwater squid Moroteuthis ingens (Cephalopoda: Onychoteuthidae): evidence for a habitat shift? Can J Fish Aquat Sci 50:2366-2374

Jackson GD (1997) Age, growth and maturation of the deepwater squid Moroteuthis ingens (Cephalopoda: Onychoteuthidae) in New Zealand waters. Polar Biol 17:268-274

Jackson GD, Mladenov PV (1994) Terminal spawning in the deepwater squid Moroteuthis ingens (Cephalopoda: Onychoteuthidae). J Zool (Lond) 234:189-201

Jackson GD, Buxton NG, George MJA (1997) Beak length analysis of Moroteuthis ingens (Cephalopoda: Onychoteuthidae) from the Falkland Islands region of the Patagonian Shelf. J Mar Biol Assoc UK 77:1235-1238

Jackson GD, George MJA, Buxton NG (1998a) Distribution and abundance of the squid Moroteuthis ingens (Cephalopoda: Onychoteuthidae) in the Falkland Islands region of the South Atlantic. Polar Biol 20:161-169

Jackson GD, McKinnon JF, Lalas C, Ardern R, Buxton NG (1998b) Food spectrum of the deepwater squid Moroteuthis ingens (Cephalopoda: Onychoteuthidae) in New Zealand waters. Polar Biol 20:56-65

Kubodera T, Shimazaki K (1989) Cephalopods from the stomach contents of the pomfret (Brama japonica Hilgendorf) caught in surface gillnets in the northern north Pacific. J Ceph Biol 1(1):71-83

Laist DW (1987) Overview of the biological effects of lost and discarded plastic debris in the marine environment. Mar Pollut Bull 18:319-326

Laptikhovsky V, Fetisov A (1999) Scavenging by fish of discards from the Patagonian squid fishery. Fish Res 41:93-97

Lipinski MR, Payne AIL, Rose B (1992) The importance of cephalopods as prey for hake and other groundfish in South African waters. S Afr J Mar Sci 12:651-662

Moreira F (1990) Food of the swordfish, Xiphias gladius Linnaeus, 1758, off the Portuguese coast. J Fish Biol 36:623-624

Parin NV, Kukuyev YI (1983) Reestablishment of the validity of Lampris immaculatus Gilchrist and the geographical distribution of Lampridae. J Ichthyol 23:1-12

Pruter AT (1987) Sources, quantities and distribution of persistent plastics in the marine environment. Mar Pollut Bull 18:305-310

Prut'ko VG (1979) On the occurrence of the Opah, Lampris guttatus (Osteichthyes, Lampridae) in the southern part of the Indian Ocean. J Ichthyol 19:140-141

Salini JP, Blaber SJM, Brewer DT (1992) Diets of sharks from estuaries and adjacent waters of the North-eastern Gulf of Carpentaria, Australia. In: Pepperell JG (ed) Sharks: biology and fisheries. Aust J Mar Freshw Res 43:87-96

Seki MP (1993) Trophic relationships of Ommastrephes bartramii during winter migrations to subtropical waters north of the Hawaiian Islands. In: Okutani T, O'Dor, RK, Kubodera $\mathrm{T}$ (eds) Recent advances in cephalopod fisheries biology. Tokai University Press, Tokyo, p 523-529

Smale MJ (1994) Cephalopods as prey. IV. Fishes. Phil Trans R Soc Lond B 351:1067-1081

Stevens JD (1973) Stomach contents of the blue shark (Prionace glauca L.) off south-west England. J Mar Biol Assoc UK 53:357-361

Toll RB, Hess SC (1981) Cephalopods in the diet of the sword- 
fish, Xiphias gladius, from the Florida Straits. Fish Bull 79: 765-774

Van Franeker JA, Bell P (1988) Plastic ingestion by petrels breeding in Antarctica. Mar Pollut Bull 19:672-674

Waller GNH, Baranes A (1994) Food of Iago omanensis: a deep water shark from the northern Red Sea. J Fish Biol 45:37-45

Weimerskirch H, Cherel Y, Cuenot-Chaillet F, Ridoux V (1997) Alternative foraging strategies and resource allocation by male and female wandering albatrosses. Ecology 78: 2051-2063

Wetherbee BM, Gruber SH, Cortes E (1990) Diet, feeding habits, digestion, and consumption in sharks, with special reference to the lemon shark, Negaprion brevirostrus. In:

Editorial responsibility: Otto Kinne (Editor),

Oldendorf/Luhe, Germany
Pratt HL Jr, Gruber SH, Taniuchi T (eds) Elasmobranchs as living resources: advances in the biology, ecology, systematics, and the status of the fisheries. US Department of Commerce, NOAA Tech Rep NMFS 90, Silver Spring, $\mathrm{MD}, \mathrm{p} 29-47$

Wolfe DA (1987) Persistent plastics and debris in the ocean: an international problem of ocean disposal. Mar Pollut Bull 18:303-305

Yamamura O, Inada T, Shimazaki K (1993) Predation on firefly squid Watasenia scintillans by demersal fishes off Sendai Bay, North Japan. In: Okutani T, O'Dor RK, Kubodera $\mathrm{T}$ (eds) Recent advances in cephalopod fisheries biology. Tokai University Press, Tokyo, p 633-639

Submitted: December 29, 1999; Accepted: April 18, 2000 Proofs received from author(s): October 9, 2000 